\title{
Effectiveness of Farmer Groups in Managing Business Units for Farmer Empowerment
}

\author{
Sri Hanggana ${ }^{1}$, Suwarto ${ }^{1}$, Bandi $^{1}$, and Sapja Anantanyu ${ }^{1}$ \\ srihanggana_fe@staff.uns.ac.id, suwarto56@staff.uns.ac.id, Bandi@ staff.uns.ac.id, \\ sapja anan@staff.uns.ac.id \\ ${ }^{1}$ Universitas Sebelas Maret, Indonesia
}

\begin{abstract}
This study aims to assess the effectiveness of farmer groups in managing business units and identify problems that reduce the effectiveness of farmer groups. The research location was in Kebakkramat District, Karanganyar Regency. The objects of this research were the farmer groups that manage government-assisted tractors. The data collection techniques used in-depth interviews, focus group discussions, and documents. The results of the research were that there was only one effective farmer group, while the other nine farmer groups were less effective. Problems that reduced the effectiveness of farmer groups were difficulties in adding marketing areas, limited tractor operators, difficulties to gather members, and members are reluctant to become managers. Only the government will be able to overcome the problems by issuing regulations to form business entities and expand marketing.
\end{abstract}

Keywords: Farmer groups, effectiveness of farmer Groups, business entity, farmer empowerment

\section{Introduction}

The objectives of farmer empowerment are developing farmers, increasing farm profits, and developing farmer groups into Farmer-Owned Enterprises (BUMP) [1]. Farmer's Institutions began with the formation of farmer groups. A farmer group is a group of farmers/breeders/planters formed by farmers based on common interests, similarity in social, economic, and resource conditions, common commodities, and familiarity to improve members' businesses [2].

Farmer groups have a role in representing farmers in getting for their interests to the government [3], increasing the scale of member businesses, and distributing government assistance to farmers [4]. The Ghanaian government is more effective in developing farmer institutions to strengthen innovation systems agricultural mechanization compared to subsidizing machines [5]. The benefits of farmer groups for members include increased productivity and more efficiency [6] [7], increased farmers' income [8], strengthening farmers' access to markets [9] [10] [11], a place to solve farming problems [12], and accelerating farmers to adopt technological innovations [13]. Other benefits are reducing exploitation and opportunistic behavior of traders 
buying agricultural products [14], reducing transaction costs [15] [16]. As of October 2018, the government has established 587,464 farmer groups, 68,392 combine farmer groups, and assigned 67,518 Field Agricultural Extension Officers (PPL) [17].

The government provides agricultural tools and machinery to farmer groups for capital to establish a business unit for renting agricultural tools and machinery (UPJA) [18]. UPJA is a business-oriented professionally managed in order to gain profits and expand investment. Most farmers (96\%) stated that agricultural tools and machines were needed in rice farming [19]. The benefits of agricultural mechanization are to overcome labor shortages, increase agricultural productivity, and overcome the adverse effects of climate change [20] [21], harvesting activities are more efficient in terms of labor, cost, and time, and reduce yield losses, [22].

The Operational Officer (PO) at the Office of Agricultural Extension Center (BPP) Kebakkramat District annually makes an inventory report of the UPJA which is reported to the Department of Agriculture, Food, and Fisheries of Karanganyar Regency. Based on an in-depth interview on 11 February 2021 with Ms. Herni Puji Astuti as the UPJA 2020 inventory report maker, information was obtained: (a) The government has provided 44 agricultural machinery equipment assistance units to 4 Combine Farmer Groups and 25 Farmer Groups in the 2014-2020 period. (b) Combine farmer groups and farmer groups failed to realize the government's goal, which were to become a BUMP with a legal entity and had not been able to provide rental prices to members that were cheaper than the market price. This study aims to assess the effectiveness of farmer groups in managing business units and identify problems that can reduce effectiveness of farmer groups.

\section{Methodology}

This study was used a qualitative method with a multi-case approach. The qualitative method is chosen because it is suitable for understanding the meaning behind visible data, understanding social interactions, and understanding people's feelings [23]. The qualitative method is used to examine natural conditions, researchers as instruments for data collection [24]. Case studies are chosen to describe contemporary, broad, deep, and real-world conditions [25].

The study was conducted from February to July 2021. The research location was in Kebakkramat District, Karanganyar Regency, Central Java Province. Kebakkramat District was chosen because it was known as a central rice-producing area in Karanganyar Regency. Kebakkramat has 5,909 hectares of rice fields. This is the widest in Karanganyar, and in 2018 it produced 38,703 tons of grain being the highest grain producer in Karanganyar Regency [26].

The objects of this research were farmer groups that manage government-assisted tractors. The reasons were: (a) machinery assistance in the form of 58\% tractors, (b) all farmers already use tractors, while not all farmers use transplanter, harvesting machine, and water pumps. Informants who come from PPL were selected according to their place of work. Informants from members and managers were selected using the snowball sampling method. Data collection techniques were done by in-depth interviews, focus group discussions, and documents. The 
research instrument was the researcher and interview guide. Qualitative data were analyzed using an interactive model [27].

\section{Result and Discussion}

Kebakkramat district has 10 combined farmer groups and 55 farmer groups, 10 villages, 7,181 farmers, 2,438 hectares of rice fields, average rice field ownership is 0.4 hectares per farmer, and plants rice three times per year [26]. The numbers of informants from the managers of the farmer groups were 10 people, the members were 33 people, and the PPL were 7 people. Total of informants were 50 people. Each village was represented by 1 farmer group which was assessed by PPL as having relatively active.

\subsection{Effectiveness of Farmer Groups in Managing Business Units}

The effectiveness of farmer groups in managing tractor business units for farmer empowerment is measured by the success rate of farmer groups in realizing farmer empowerment goals. The more goals of farmer empowerment that are successfully realized, the higher the effectiveness of farmer groups. The effectiveness of farmer groups after receiving tractor assistance was measured by dimensions of effectiveness [1] [2].

1) Tractor rental prices to members are cheaper than market prices, thereby lowering crop cultivation costs and increasing profits.

2) Savings to develop independent and highly competitive business units.

3) Pay salary to the managers according to the rights and obligations.

4) High-quality work, at least equal to competitors, so as to increase crop production yields.

5) Provide services, at least equal to competitors, so that members become loyal customers.

6) Provide assistance for the implementation of the extension carried out by PPL.

7) Provide assistance for The distribution of government assistance to farmers without complaints from members and PPL.

Assessment of effectiveness farmer groups is categorized into three, namely effective, less effective, and ineffective levels. Goals that have been realized get a high score (T), and those that have not been realized are rated low $(\mathrm{R})$. The following are the criteria for the effectiveness of farmer groups: a) Farmer groups with a T value of 6 to 7 are considered effective.; b) T values of 3 to 5 are considered less effective.; c) T values of 1 and 2 are considered ineffective.

Based on the effectiveness value of farmer groups in table 1, it is known that only one farmer group is valued effective, while nine farmer groups are valued less effective. The Pulo Makmur farmer group in Pulosari Village has a $T$ value of six, so it gets an effective value. The other nine farmer groups get a $\mathrm{T}$ score of three, so they get a less effective value. The subdimensions that have been able to be realized by all farmer groups or the number of $T=10$ are sub-dimensions number 4 (quality of work), 6 (assisting extension), and 7 (distribution of assistance). Farmer groups assisting in extension and distributing assistance have been carried out since before receiving tractor capital assistance. The sub-dimension that has not been able to be realized by all farmer groups or the number of $T=0$ is sub-dimension number 5 , namely service that satisfies members. This happens because all farmer groups only have one tractor, so they are not able to serve all members. One tractor is only able to tractor 7-8 hectares per crop season to 
carry out simultaneous planting decisions. Meanwhile, the area of rice fields for each farmer group is more than 30 hectares. As a result, many members were disappointed that the tractor was not there when needed. The sub-dimensions that can only be realized by one farmer group or the number of $\mathrm{T}=1$ are sub-dimensions number 1 (lower rental prices), 2 (having savings), and 3 (professionals by giving salaries to managers).

Table 1. Effectiveness Value of Farmer Groups in Managing Tractor Business Units

\begin{tabular}{llllllllllll}
\hline No. & \multicolumn{1}{c}{ Farmer Groups } & Village & \multicolumn{4}{c}{ Dimensions of Effectiveness } & \multicolumn{3}{c}{ Total } \\
\hline & & 1 & 2 & 3 & 4 & 5 & 6 & 7 & $\mathrm{~T}$ & $\mathrm{R}$ \\
1. Sedyo Utomo & Waru & $\mathrm{R}$ & $\mathrm{R}$ & $\mathrm{R}$ & $\mathrm{T}$ & $\mathrm{R}$ & $\mathrm{T}$ & $\mathrm{T}$ & 3 & 4 \\
2. Pulo Makmur & Pulosari & $\mathrm{T}$ & $\mathrm{T}$ & $\mathrm{T}$ & $\mathrm{T}$ & $\mathrm{R}$ & $\mathrm{T}$ & $\mathrm{T}$ & 6 & 1 \\
3. Simo Makmur & Macanan & $\mathrm{R}$ & $\mathrm{R}$ & $\mathrm{R}$ & $\mathrm{T}$ & $\mathrm{R}$ & $\mathrm{T}$ & $\mathrm{T}$ & 3 & 4 \\
4. Sido Mulyo & Malangganten & $\mathrm{R}$ & $\mathrm{R}$ & $\mathrm{R}$ & $\mathrm{T}$ & $\mathrm{R}$ & $\mathrm{T}$ & $\mathrm{T}$ & 3 & 4 \\
5. Rejo Mulyo & Kaliwuluh & $\mathrm{R}$ & $\mathrm{R}$ & $\mathrm{R}$ & $\mathrm{T}$ & $\mathrm{R}$ & $\mathrm{T}$ & $\mathrm{T}$ & 3 & 4 \\
6. Jati Mulyo & Banjarharjo & $\mathrm{R}$ & $\mathrm{R}$ & $\mathrm{R}$ & $\mathrm{T}$ & $\mathrm{R}$ & $\mathrm{T}$ & $\mathrm{T}$ & 3 & 4 \\
7. Ngudi Mulyo & Kemiri & $\mathrm{R}$ & $\mathrm{R}$ & $\mathrm{R}$ & $\mathrm{T}$ & $\mathrm{R}$ & $\mathrm{T}$ & $\mathrm{T}$ & 3 & 4 \\
8. Ngudi Makmur & Lebak & $\mathrm{R}$ & $\mathrm{R}$ & $\mathrm{R}$ & $\mathrm{T}$ & $\mathrm{R}$ & $\mathrm{T}$ & $\mathrm{T}$ & 3 & 4 \\
9. Ngudi Waras & Nangsri & $\mathrm{R}$ & $\mathrm{R}$ & $\mathrm{R}$ & $\mathrm{T}$ & $\mathrm{R}$ & $\mathrm{T}$ & $\mathrm{T}$ & 3 & 4 \\
10. Tani Mulyo & Alastuwo & $\mathrm{R}$ & $\mathrm{R}$ & $\mathrm{R}$ & $\mathrm{T}$ & $\mathrm{R}$ & $\mathrm{T}$ & $\mathrm{T}$ & 3 & 4 \\
& Total T & 1 & 1 & 1 & 10 & 0 & 10 & 10 & & \\
& Total R & 9 & 9 & 9 & 0 & 10 & 0 & 0 & & \\
\hline
\end{tabular}

Source: Informans from PPL, Managers and members of famer groups.

\subsection{The Problems Faced by the Managers of The Farmer Groups}

The problems faced by the managers show in Table 2. The problems are: (1) difficulties in adding marketing areas, support finding [28]; (2) limited tractor operators, support finding [29]; (3) difficulties to gather members; (4) members are reluctant to become managers, support finding [30].

The tractor marketing area has been allocated for a long time as a solution to overcome the shortage of tractors to carry out simultaneous planting programs. At first all the tractors were privately owned, and every village lacked tractors. Finally, many farmers were looking for tractors from outside the area so that they can participate in planting simultaneously. According to the nature of business, if demand is greater than supply, then the price is high and the entrepreneur's profit is also high. This attracts many people to invest in tractors. On the other hand, the government also provides tractor and other machinery assistance programs to meet the needs of farmers so that they are able to plant simultaneously. Eventually the operating tractors became too many. To prevent disputes and maintain the simultaneous planting program, village level meetings were held to regulate the allocation of marketing areas and tractor rental prices.

The area allocation for each tractor was initially wide, so that in one village it was completed in 3 to 4 weeks. After many people invested in tractors and the existence of tractor assistance programs, now tractors are redundant. On average, one village completed 2 weeks. With this condition, the management is unable to increase the work area. This was stated by the informant, Mr. Sartono, the managers of the Pulo Makmur farmer group. 
"In Pulosari Village, there are 27 tractors with 187 hectares of rice fields. So according to the policy at the village meeting, it is divided equally, so that each tractor is only about 7 hectares. Tractors outside the village are not allowed. Seven hectares takes 14-15 working days on average."

Managers of farmer groups face the problem of operator availability. Only a few people are willing to become operators, as a result, the management of farmer groups is often unable to compete for operators with individual tractor owners. This resulted in the marketing area being taken by individual tractors that are one block away. This incident is indeed allowed, because the tractor area is divided based on blocks. One block is done by 2 to 4 tractors according to the area. Farmers choose tractors with the main consideration that the tractor is there when needed, not considering belonging to farmer groups or individuals. Farmer groups find it difficult to find operators because few people are willing to become operators. Young people are not interested in being a tractor operator because they need a strong body to walk in the mud of the rice fields and the heat of the sun. Operator salaries are relatively high, an average of IDR 150,000 to IDR 200,000 per day plus food allowance. This salary is higher than the salary of a factory worker with a high school education, which is an average of IDR 100,000 per day. Learning to be a tractor operator is easy, without any special education. So far, operators are learning while working to become operator assistants. After one planting season, they are able to become operators in the next planting season. People who are willing to become operators are generally unskilled workers, have low education, and have strong energy.

Managers of farmer groups face the problems of difficult to gather members. This problem is experienced by all farmer roups (total 10). Some of the reasons members do not attend regular farmer group meetings include being lazy because farming is just a sideline, not much new information, and being able to ask other members. This causes many farmer group managers not to hold regular member meetings, in addition to the reasons members are reluctant to attend, it is also difficult to meet the cost of meeting consumption. The managers who managed to hold regular meetings were the Pulo Makmur farmer group in Pulosari village, Simo Makmur in Macanan village, Sri Makmur in Maalangganten village, Sri Mulyo in Alastuwo village, and Rejo Mulyo in Kaliwuluh village. The average attendance rate is below $50 \%$ of the members. Some farmer groups charge meeting consumption costs to members, while there are farmer groups that use farmer group cash to finance meeting consumption.

Managers of farmer groups face the problem of members' reluctance to become managers, except for the Pulo Makmur farmer group. Members of the Pulo Makmur farmer group have relatively no difficulty finding members who are willing to become managements. According to the informant, Mr. Sartono as the managers of the farmer group, this is because the management is paid according to their duties and responsibilities. The managers is paid according to the regional minimum wage (UMR), while the other managements are slightly less. They realized that being a chairperson had many tasks, had the risk of being scolded by members and PPL, but did not receive compensation. For example, the incident told by the informant, Mr. Sunarmo, the managers of the Sri Makmur farmer group, Malangganten village. 
"Actually, my term of office is 5 years only until June 2020, but because every routine meeting on the 2 nd there is no member who wants to be managers, the managers election meeting has been postponed. Finally, someone could be persuaded to be willing to become managers, and an election for the board was held at a routine meeting on March 2, 2021. The result was Mr. Desi Sri Ratno as managers. But after two months, at a regular meeting on May 2, 2021, he resigned. Finally, I was appointed as interim managers"

Table 2. Problems Faced by Farmer Groups Managers

\begin{tabular}{llllllllllllll}
\hline No. & \multicolumn{1}{c}{ Problems } & \multicolumn{1}{c}{ Famer Groaups } \\
\cline { 2 - 13 } & A & B & C & D & E & F & G & H & I & J & TTL \\
\hline 1. Difficult to add marketing area & 1 & 1 & 1 & 1 & 1 & 1 & 1 & 1 & 1 & 1 & 10 \\
2. & Limited number of operators & 1 & 1 & 1 & 1 & 1 & 1 & 1 & 1 & 1 & 1 & 10 \\
3. Difficulty of gathering members & 1 & 1 & 1 & 1 & 1 & 1 & 1 & 1 & 1 & 1 & 10 \\
4. & Members are reluctant to become managers & 1 & 0 & 1 & 1 & 1 & 1 & 1 & 1 & 1 & 1 & 9
\end{tabular}

Notes:

A = Sedyo Utomo; B = Pulo Makmur; $\mathrm{C}=$ Simo Makmur; $\mathrm{D}=$ Sido Mulyo; E = Rejo Mulyo;

F = Jati Mulyo; $\mathrm{G}=$ Ngudi Mulyo; $\mathrm{H}$ = Ngudi Makmur; $\mathrm{I}=$ Ngudi Waras; $\mathrm{J}=$ Tani Mulyo.

$1=$ Managers got a problem

$0=$ Managers did not get a problem

Source: Informans from Managers and members of famer groups.

\section{Discussion}

Government assistance in the form of tractors and other machinery becomes an asset for organizations to create value so that the assistance becomes social capital farmer groups [31]. However, farmer groups have not been able to manage social capital in the form of tractors to empower farmers [32]. Farmer groups are formed by the government based on a series of regulations, not the will of the members and managers. This has resulted in the managers of farmer groups not being able to overcome the problem. To overcome this problem, the government must issue regulations to expand marketing and form business entities to manage business units. If this is not done, then the farmer groups are less effective in managing the business unit.

\section{Conclusion}

Only one farmer group was effective to manage business units for farmer empowerment, while the other nine farmer groups were less effective. Farmer group managers faced problems such as difficulty in adding marketing areas, difficulty in getting tractor operators, difficulty in gathering members, and difficulty in getting members who are willing to become managers. The managers of farmer groups not being able to overcome the problem. Only the government will be able to overcome the problems by issuing regulations to form business entities and expand marketing. 


\section{Acknowledgement.}

I would like to thank the Rector University of Sebelas Maret, Coordinator of PPL and PPL at the Office of Agricultural Extension Center, as well as managers and members of farmer groups in Kebakkramat District.

\section{References}

[1] Undang-Undang Nomor 19: Tentang Perlindungan dan Pemberdayaan Petani (2013).

[2] Peraturan Menteri Pertanian nomor 273/Kpts/OT.160/4: Tentang Pedoman Pembinaan kelompok tani dan gabungan Kelompok tani (2007).

[3] Wang, J., Z. Hochman, B. Taylor, T, Darbas, H. Rees, P. Carberry, and D. Ren. 2017. Governing through Representatives of The Community: A Case Study on Farmer Organizations in Rural Australia. Journal of Rural Studies, Vol. 53, p. 68-77 (2017).

[4] Syahyuti, S. Wahyuni, R. N. Suhaeti, and A. K. Zakaria. Policy Path after Revision of the Farmers Protection and Empowerment Act. Analisis Kebijakan Pertanian, Vol. 12, No. 2, p. 157-174 (2014).

[5] Daum, T. and R. Birner. The Neglected Governance Challenges of Agricultural Mechanisation in Africa-insights from Ghana. Food Security, Vol. 9, No.5, p. 959-979 (2017.

[6] Bairagi, S. and K. A. Mottaleb. Participation in Farmers' Organization and Production Efficiency: Empirical Evidence from Smallholder Farmers in Bangladesh. Journal of Agribusiness in Developing and Emerging Economies. Vol. 11, No. 2, p. $73-87$ (2012).

[7] Tolno, E., H. Kobayashi, M. Ichizen, M. Esham, and B. S. Balde. Economic Analysis of the Role of Farmer Organizations in Enhancing Smallholder Potato Farmers' Income in Middle Guinea. Journal of Agricultural Science, Vol. 7, No. 3, p. 123-137 (2015).

[8] Desiana, N. and A. Aprianingsih. Improving Income through Farmers' Group Empowerment Strategy. The Asian Journal of Technology Management, Vol. 10, No. 1, p. $41-47$ (2017).

[9] Hamilton, W., G. Bosworth, and E. Ruto. Entrepreneurial younger farmers and the "young farmer problem" in England. Agriculture and Forestry. Vol. 61, No. 4, p. $61-69$ (2015).

[10] Frese, M. and M. M. Gielnik. The psychology of entrepreneurship. Annual Review of Organizational Psychology and Organizational Behavior. Vol. 1, p. 413-38 (2014).

[11] Abdul-Rahaman, A. and A. Abdulai. Farmer Groups, Collective Marketing and Smallholder Farm Performance in Rural Ghana. Journal of Agribusiness in Developing and Emerging Economies, Vol. 10, No. 5, p. $511-527$ (2020).

[12] Suratini and J. Hadipurwanta. Efektivitas Fungsi Kelembagaan Kelompok Tani di Kecamatan Dumoga Timur Kabupaten Bolaang Mongondow. Halaman 620-633. Prosiding Seminar Nasional:Agroinovasi Spesifik Lokasi untuk Ketahanan Pangan Pada Era Masyarakat Ekonomi ASEAN. URI-http://repository.pertanian.go.id/handle /123456789, (2017).

[13] Adawiyah, C. R., Sumardjo, and Eko S. M. Faktor-Faktor yang Memengaruhi Peran Komunikasi Kelompok Tani dalam Adopsi Inovasi Teknologi Upaya Khusus (Padi, Jagung, Dan Kedelai) di Jawa Timur. Jurnal Agro Ekonomi, Vol. 35 No. 2, p. 151-170 (2017). 
[14] Sathapatyanon, J.K.M. Kuwornu, G.P. Shivakoti, P. Soni, A.K. Anal, and A. Datta. The role of farmer organizations and networks in the rice supply chain in Thailand. Journal of Agribusiness in Developing and Emerging Economies, Vol. 8, No. 3, p. 554-578 (2018).

[15] Mbeche, R.M. and P. Dorward. Privatisation, Empowerment and Accountability: What Are the Policy Implications for Establishing Effective Farmer Organisations? Land Use Policy. vol. 36, p. 285-295 (2014).

[16] Yang, D. and Z. Liu. Does Farmer Economic Organization and Agricultural Specialization Improve Rural Income? Evidence from China. Economic Modelling, Vol. 29, p. 990-993 (2012).

[17] Pusat Data dan Informasi Pertanian Sekretariat Jenderal Kementerian Pertanian. Statistik Pertanian 2018. http://epublikasi.setjen.pertanian.go.id /epublikasi/Statistik-Pertanian/2018/ Statistik\%20Pertanian\%202018/files/assets/basichtml/page401.html. Diakses 8 Ags (2018).

[18] Kementerian Pertanian. Peraturan Menteri Pertanian Republik Indonesia No. 25/Permentan/ PL.130/5/2008. Tentang Pedoman Penumbuhan dan Pengembangan Usaha Pelayanan Jasa Alat dan Mesin Pertanian (2008).

[19] Subagiyo and B. Setyono.. Analisis Kebutuhan Alsintan dalam Usaha tani Tanaman Pangan (Padi) di Daerah Istimewa Yogyakarta. Halaman 938-943, Buku I. Membangun Pertanian Modern dan inovatif berkelanjutan dalam Rangka Mendukung MEA. Prosiding seminar nasional 2016. Balai Besar Pengkajian dan Pengembangan Teknoligi Pertanian. Badan Penelitian dan Pengembangan Pertanian, Kementan (2016).

[20] Aryal, J. P., D. B. Rahut, G. Thapa, and F. Simtowe. Mechanisation of small-scale farms in South Asia: Empirical evidence derived from farm households survey. Technology in Society. Vol. 65.101591, p. 1-14 (2021).

[21] Qing, Y., M. Chen, Y. Sheng, and J. Huang. Mechanization Services, Farm Productivity and institutional Innovation in China. China Agricultural Economic Review. Vol. 11, No. 3. p. 536-554 (2019).

[22] Purwantini, T. B. and S. H. Susilowati. Dampak Penggunaan Alat Mesin Panen terhadap Kelembagaan Usaha Tani Padi. Analisis Kebijakan Pertanian, Vol. 16, No.1, p. 73-88 (2018).

[23] Murdiyanto, E. Penelitian Kualitatif: Teori dan Aplikasi disertai contoh proposal. Lembaga Penelitian dan Pengabdian Pada Masyarakat UPN "Veteran" Yogyakarta Press. (2020).

[24] Sugiyono. Metode Penelitian Manajemen. Alfabeta. Bandung (2016).

[25] Yin, R. K. Case Study Research and Applications: Design and Methods. Sixth Edition. SAGE Publications, Inc. Los Angeles (2018).

[26] Badan Pusat Statistik Karanganyar. Tabel Luas Panen dan Produksi Padi Sawah menurut kecamatan di Karanganyar (2019).

[27] Miles, M. B. and A. M. Huberman. Qualitative Data Analysis. Second Edition. Sage Publications. Thousand Oaks. California, USA (1994).

[28] Umar, S. 2013. Pengelolaan dan Pengembangan Alsintan untuk Mendukung Usahatani Padi di Lahan Pasang Surut. Jurnal Teknologi Pertanian, Vol. 8, No. 2, p. 37-48.

[29] Mayrowani, H. dan Tri Pranadji. 2012. Pola Pengembangan Kelembagaan UPJA untuk Menunjang Sistem Usahatani Padi yang Berdayasaing. Analisis Kebijakan Pertanian. Vol.10, No.04, p. 347-360.

[30] Sugiarto. 2010. Analisis kinerja UPJA menunjang kegiatan usaha tani padi. Jurnal Penelitian Pertanian Terapan. 10(2):118-130. 
[31] Chegini, M. G., H. Alipour, and A. Zaman. The Relationship between Social Capital and Inter-organizational Entrepreneurship in Rasht Industrial City, Iran. International Journal of basic Apllied Scientific research. Vol. 2, No. 3, p. 3157-3164 (2012).

[32] Paranata, A., Wahyunadi, Akung Daeng, dan B. S. Wijimulawiani. 2012. Mengurai Model Kesejahteraan Petani. JEJAK Journal of Economics and Policy, Vol. 5, No. 1, p. 90-102. 